\title{
Implementation Evaluation and Sustainable Development of China's Religious Charity Policy
}

\author{
Xiaojie Shi ${ }^{1}\left(\mathbb{D}\right.$, Zhenxiao Fan $^{2}$ and Jianguo Gao ${ }^{1,3, * \mathbb{C}}$ \\ 1 Department of Social Work, School of Philosophy and Social Development, Shandong University, \\ Jinan 250100, China; sxj511@126.com \\ 2 Faculty of Economics and Business, Goethe University Frankfurt, 60629 Frankfurt, Germany; \\ zhenxiao.fan@outlook.com \\ 3 The Center for Judaic and Inter-Religious Studies, Shandong University, Jinan 250100, China \\ * Correspondence: gaoj@sdu.edu.cn
}

Citation: Shi, X.; Fan, Z.; Gao, J. Implementation Evaluation and

Sustainable Development of China's

Religious Charity Policy.

Sustainability 2022, 14, 1656.

https://doi.org/10.3390/su14031656

Academic Editor: Andreas Thle

Received: 12 December 2021

Accepted: 27 January 2022

Published: 31 January 2022

Publisher's Note: MDPI stays neutral with regard to jurisdictional claims in published maps and institutional affiliations.

Copyright: () 2022 by the authors Licensee MDPI, Basel, Switzerland. This article is an open access article distributed under the terms and conditions of the Creative Commons Attribution (CC BY) license (https:// creativecommons.org/licenses/by/ $4.0 /)$.

\begin{abstract}
This paper discusses the comprehensiveness of religious policy content, the feasibility of implementation, and factors that affect the impact of policy implementation. Since the reform and opening up in 1978, China's religious charities have been in a period of organizational reconstruction, and the government exercises legal administration over religious affairs, forming a dual administrative management model: the central and local government and the civil affairs department and religious department, forming the preliminary implementation framework of religious policy. Currently, government policy implementation regarding religious charity activities adopts a "policycentered, top-down" approach in an attempt to create a clear path toward policy implementation. Using the Smith policy implementation process model, combined with field research in three cities in the Shandong province, this study finds multiple limitations deterring religious charity policy execution, including: (a) government policy texts that are not comprehensive; (b) unclear responsibilities of government departments; and (c) sensitive political and social environments. There is still a long way to ensure the smooth implementation of religious charity policies.
\end{abstract}

Keywords: implementation process; religious charity policy; Smith model; policy execution

\section{Introduction and Context}

Encouraging and regulating religious charity activities is an important way for religious groups to serve society and benefit the public, as well as a beneficial practice of religion in China. This paper explores, reviews, and reflects on the policy implementation process and influencing factors of religious public welfare and charity activities from four dimensions: idealized policy, implementation organization, target group, and environmental factors, based on the Smith model of policy implementation.

\subsection{Overview of Religions and Religious Charities in China}

In China, there are five major religions: Buddhism, Taoism, Islam, Catholicism, and Christianity, with, at present, nearly 200 million believers and a total of 380,000 clerical personnel. As the White Paper by the government stated, because ordinary believers in Buddhism and Taoism do not have strict admission procedures in China, it is difficult to accurately count the number, however, it is generally believed that the number of ordinary Buddhism believers in China exceeds the number of Christians. The total population of the 10 ethnic minorities, most of whom believe in Islam, is more than 20 million, and there are more than 57,000 Islamic clerical personnel. Moreover, there are about 6 million Catholics and more than 38 million Christians, with about 57,000 and 8000 clerical personnel [1]. Notably, Asia Harvest in 2010 estimated that Protestants had 83.5 million followers, including 54 million members of the "House Church" and that number is growing [2,3]. 
In China, faith-based religious charity organizations, like other secular charity organizations, are registered as associations, private non-enterprise units, and foundations. As of the end of 2017, there were 355,000 associations in China and only 5000 registered religious social groups [4]. From 2010 to 2017, the number of faith-based private non-enterprise units showed a downward trend, from 169 to 115. Moreover, after 2018, the government has removed the category of religious organizations from the social organization data. As of 2018, there were 97 foundations with a religious background, accounting for $1.38 \%$ of the 7015 foundations in mainland China; the number of Buddhist foundations is the largest. The percentage of faith-based religious charities is low and has continued to decline in recent years, which shows the Chinese government has taken restrictions against religious organizations.

\subsection{Religious Charity Policy and Activity in China}

Since the reform and opening-up in 1978, China's government promulgated a series of "encouraging" and "supportive" religious policy texts, indicating that religious policies are treated equally to other charity policies. In 1982, the Central Committee of the Communist Party of China released "The Basic Views and Policies of the Central Committee of the Communist Party of China on Religious Issues in China's Socialist Period" [5] as the guiding policy to promote the development of religious activities during the reform period, providing that religious staff can perform service and social welfare work. In 2012, the Chinese government's six administrations, including the National Religious Affairs Administration (NRAA) and the United Front Work (UFWD) Department of the CPC Central Committee, jointly released "Opinions on Encouraging and Regulating Religious Circles' Participation in Public Welfare Charitable Activities" [6], the clearest and most guiding normative document for religious entities to perform public welfare and charity activities in China. In 2014, the State Council's "Guiding Opinions on Promoting the Healthy Development of Charity" [7] proposed encouraging religious organizations to carry out various charity activities in accordance with laws and regulations. Until 2017, the newly revised "General Provisions of Civil Law" [8] and "Regulations on Religious Affairs" [9] had clearly stated that religious groups can establish charitable undertakings in accordance with the law.

With the support of encouraging policies, an increasing number of religious groups, religious places, and individuals have begun to actively participate in charitable activities such as poverty alleviation, disaster relief, and old-age medical care, setting up charitable projects, and creating charitable organizations with religious backgrounds. Religious charity activities have a long history as important contributors to China's social welfare services [10,11]. However, China's religious activity in the reconstruction period, due to political reasons, still has deficiencies, such as within the identity of religious charity organizations, the form and scale of charitable activities, and government regulations and management methods. Meanwhile, the political sensitivity of religion, the public's acceptance of it, and the increasing emphasis on professionalism in social services make charitable activities supported by religious enthusiasm hugely challenging.

\subsection{The Smith Model}

Policy implementation is a dynamic and concrete process. It is a dynamic system of multi-party elements, such as policy implementation environment, policy implementation subject, target group, policy content, capital, and human resources. This study analyses the implementation results and influencing factors of religious charity activities policy in the current environment, based on the Smith model. In 1973, American policy scholars proposed a process model for policy implementation in Thomas Smith's "The Process of Policy Implementation". He proposed that the factors affecting policy implementation are as follows: (1) idealized policy type, (2) implementation organization, (3) target group, and (4) environmental factors [12]. These four factors provide "tensions" during the implementation of policy, and only if they are "transacted" well, can the implementation of the 
policy proceed smoothly. In the process of "transactions" it is necessary to give "feedback" based on the problems found; if no problems are found, "feedback" through "institutions" will result in a new policy formulation process. Based on the fact that the current Chinese society is a party-state society or centralized society, different from a "democratic country", where it is determined that social organizations are strictly restricted by the state and the government occupies a dominant position in charity activities. Therefore, this paper takes the Smith model as the research framework, combined with Chinese society and political environment to analyze the comprehensiveness of existing religious charity policy system content, the feasibility of implementation, and the factors that affect the impact of policy implementation and propose improvements to the structure of religious charity policies.

\subsection{Research Questions and Methodology}

This study attempts to answer some questions regarding the religious charities policy in China: What are the current types of religious charity policy? How do government agencies implement policies to support the government? How does the religious charities policy target group affect implementation? Is the current political environment in China conducive to religious policies? What are the developmental features of the religious charities policy since 1978? In what ways are factors "tensions" during the implementation of policy?

The methodology of this study was based on the document research method [13]. Three types of data were used primarily: official government documents, academic literature, and case information. Official government documents refer to laws, government regulations, work reports; academic literature, including articles, books, comments, reviews, and; case information, including field research information, websites (such as charity organizations, national or local government departments), and newspapers. This paper sorts out and analyzes the existing kinds of literature according to the research theme, tries to reveal factors that affect the impact of policy implementation, and puts forward suggestions for the sustainable development of the policy. The analytical approaches in this study include literature review, content analysis, system function analysis, and feature and attribute analysis.

\section{Analysis of the Policy Implementation Process of Religious Charity Activities}

\subsection{The Idealised Policy Type}

An idealized policy is considered a prerequisite for the effective implementation of policy in the Smith model. Idealized policy types can only be implemented smoothly if they have the characteristics of being reasonable, legal, and feasible. When analyzing China's policies on encouraging and supporting religious groups to participate in public welfare and charitable activities, and based on the nature, subject, scope of application, and legal effect of the policy, they are divided into national laws, administrative regulations, departmental rules, local government laws and regulations, religious policy texts, policy interpretations, white papers, and relevant rules and regulations of state religious groups. According to the perspective of the policy or regulation, these are further divided into national laws, state council administrative rules, local government regulations and rules, and relevant canons and systems of national religious groups (Figure 1). According to state council and provincial (autonomous region and municipality) statistics, under the "Constitution of the People's Republic of China", China has formulated two comprehensive religious administrative regulations, 12 religious department regulations, and 17 relevant religious policies and regulations of the party. In order to implement the "Regulations on Religious Affairs" [9], "Opinions on Encouraging and Regulating Religious Circles' Participation in Public Welfare Charitable Activities" [7], and other upper-level law on the religious community's participation in public welfare and charity services, many provinces and cities have issued more than 60 local government regulations, as normative documents. For example, in 2015, the Ethnic and Religious Affairs Commission (ERAC) of Shandong Province issued the "Plan on Organising the Province's Religious Circles to carry out Public 
Welfare Activities" [14], and the Ethnic and Religious Affairs of Jinan City (Shandong Province) issued the "Implementation Opinions on Encouraging and Regulating Religious Circles to Engage in Public Welfare and Charity Activities" [15]. Some provinces and cities have also innovated on prior content, based on their actual conditions, and absorbed its practice in local religious affairs. For example, Jiangsu Province proposed "cultivating and building a charity brand for the religious community in Jiangsu Province". In recent years, national religious groups have also been actively exploring and formulating canon systems to serve society. In 2018, the China Christian Council (CCC) and the National Committee of the Three-Self Patriotic Movement of the Protestant Church in China (TSPM) jointly proposed a plan to encourage Christian groups, organizations, and believers to participate in social charity by request under the "Outline of the five years plan for Promoting the Indigenisation and Contextualisation of Christianity in China (2018-2022)" [16,17]. From the specificity and comprehensiveness of the policy content, the existing policies clearly state that the government encourages and supports religious groups to engage in charitable activities. The specific measure is to encourage the religious community to establish and register social organizations, support the religious community to develop social services, online government supervision, and evaluation systems in multiple fields, and enjoy other support and preferential measures, alongside secular social service organizations.

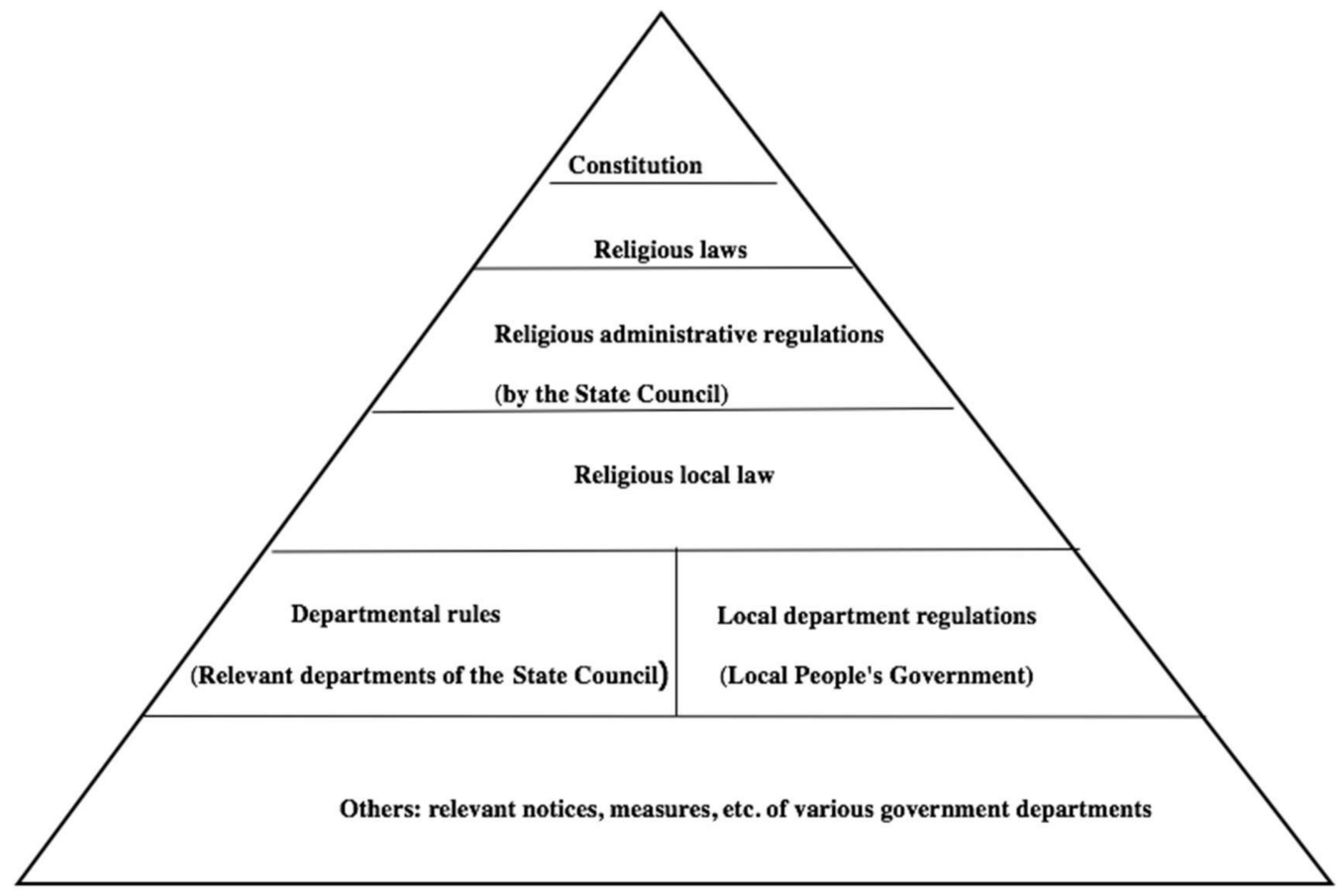

Figure 1. Classification Map of Religious policies.

However, China has not yet adopted basic national laws on religion, such as a religious law, and other religious laws and policies are at a lower level. China's religious affairs have formed an institutional framework supplemented by numerous laws and regulations based on the "Regulations on Religious Affairs" [9]. However, the "Regulations on Religious Affairs" are only administrative regulations, promulgated by the China State Council, and their legal effect is not strong. Currently, the policy texts on religious charity activities only focus on administrative regulations, departmental rules, and regulatory documents, such as notifications, opinions, and responses that have no real legal effect. These documents themselves have obvious policy characteristics, with a certain degree of arbitrariness that results in the lack of a solid policy basis and norms in the implementation [18]. Thus, for such policies, the approach has typically been "cure the symptoms, not the disease". In addition, the content of the current religious charity policy lags behind the status quo 
of religious development. Taking religious network charity as an example, the religious community does not have relevant policies and laws when conducting network charity activities, such as fundraising. "Regulations on the Administration of Religious Activity Sites" restrict the management of religious activities to traditionally fixed churches and temples, while the policy content of online charities is lacking. All this shows that the Chinese government is trying to relax overly strict administrative restrictions, but it does not want to protect rights based on the rule of law, so as to achieve control over religious charitable organizations and charitable activities.

\subsection{Analysis of the Implementation Agency of the Policy of Religious Public Welfare and Charity Activities}

Currently, the policy implementation of religious charity activities adopts a "policycentric, top-down" approach. The operation of the executive agency is indispensable for the smooth implementation of the policy. In the actual implementation process, if the behavior of the executive agency deviates from the policy's ideal goal, this will lead to the phenomenon of policy "blocking" and "alienation". In the Smith policy implementation model, the executive agency has three main variables: organization and personnel (organizational stability and the understanding process of the executive), the leadership of the administrative organization (leadership style and nature), and the implementation plan and ability (the intensity of the organization, concern, and ability) [12]. Therefore, the executive agency that analyses the policy mainly studies the execution behavior of national and local government departments at the dynamic level and leadership style, management style, and attitude of the administrative organization at the static level.

Analysing the current implementing agencies for religious charitable activities, at the national level are the NRAA and the UFWD; and at the local level are the localised UFWD and the Religious Affairs Administration of the provinces, autonomous regions, and municipalities. Thus, the "dual management pattern" of religious public welfare and charity affairs has been formed, reflected in the increasingly clear responsibilities of government departments. The civil affairs department is responsible for the registration of agencies or organizations, supervising religious groups in carrying out disaster relief and poverty alleviation activities, and the religious departments are responsible for the supervision and regulation of affairs involving religious issues in organizations or activities. Each department performs its duties to manage and serve religious affairs.

Although the "dual management pattern" has been formed, the contradiction of multiple supervision still exists, especially in terms of religious public welfare and charity services, there is no unified supervisory department and administrative management is overlapping, meaning that the terms of reference are vague and unclear. Take the Shende Christian pension institution in Weifang City, Shandong Province as an example. The funds and objects donated by believers are directly managed by the local committee of the TSPM. The registration issue is managed by the local civil affairs department. The local committee of the TSPM and other religious affairs are under the management of the religious affairs department. Given that the integration of medical and elder care has become a hot-button issue for elderly care, capital intervention in elderly care institutions is a typical feature, and the supervision of banks and other financial and taxation systems also puts pressure on the daily management and operation of institutions. In addition, most religious charity organizations are inspected and guided by their neighborhood committees (grassroots political and administrative organizations in China) due to their political sensitivity, resulting in the "one institution, multiple management" phenomenon. When implementing specific policies, implementing agencies must coordinate and cooperate with various departments. As long as there is a problem in one link, the entire implementation process will be blocked, and the ultimate impact of the policy will be affected. In addition, due to the lack of clear provisions on the functions of the executive subject in relevant policies and regulations, and because relevant departments often have a cautious, wait-and-see attitude towards religious participation in public charity services, there is a lack of functionality. Meanwhile, 
due to this lacking functionality, the supervision and management responsibilities are usually shouldered by local UFWDs or religious departments, causing inconsistencies.

The leadership style, management style, and attitude of the administrative organization play an important role in the smoothness of the policy implementation process and are key to its effectiveness. In the new century, especially after the release of the "Regulations on Religious Affairs" [9] and "Opinions on Encouraging and Regulating Religious Circles' Participation in Public Welfare Charitable Activities" [6], the government's focus on religious affairs management has gradually changed from that of religious groups and places of religious activity to actively guiding religious groups and believers to shoulder social responsibilities and fulfill social missions [19-22]. The management mode is also experiencing a stage of transformation from a united front approach to a rule of law management style. However, for a long time, the politics of religious management, the universality and complexity of the content and form of religious affairs, and the strictly limited "inertia" thinking, have led some local religious management departments to have a working style of unwilling, bad, and excessive management, the result of government and religious agencies have not been able to sort out for a long time. In some areas, the normative management effect is greater than the encouraging effect, and they tend to use the rigid management method of administrative orders and the rule of individuals without protection, encouragement, and guidance. The policy implementation agency focuses on results and short-term effects, ignoring the long-term impact of religious charity. However, some local governments tend to foster and incubate religious service institutions and give institutions more relaxed policy flexibility and preferential conditions, with obvious regional gaps. It reflects that although the Communist Party of China and the national government have released the concept of encouragement and support, the long-term management effect of strict constraints on religion still has a great impact on local governments.

\subsection{Analysis of Policy Target Groups}

The target group is an important internal factor that affects policy implementation. Smith believes that a target group refers to the group that needs to adapt to the policy and make its own changes, including the organization or institutionalization of the group, the leadership of the group, and the experience of existing policies. Whether the results of policy implementation can achieve the expected goals depends to a large extent on the target groups' attitudes and practices towards the policy. If the target group accepts, approves, and complies with the policy, its implementation proceeds smoothly, whereas the opposite will hinder policy implementation. In terms of religious charity activities, the target group refers to religious groups, religious non-profit organizations, and religious foundations. Based on their belief principle, religious communities offer their service advantages and specialties in specific fields and have become an important force in the field of public welfare and charity [23]. Some social service institutions with religious backgrounds or charity organizations have organized disability and elderly care service institutions to meet the service needs of special groups [24-29], such as for people with rare diseases, the elderly, and the disabled. Taking Shandong Province as an example, by 2017, there were more than 40 charitable organizations such as nursing homes, foundations, and medical rehabilitation centers set up by religious groups, including 27 elderly care service institutions, covering an area of more than 330 acres with a construction area of more than 60,000 square meters. There are more than 1500 elderly care rooms and more than 3300 beds, and 2000 people have been accommodated [30].

The faith factor or religious factor is one of the most obvious characteristics of religious charity, and it is also a fundamental factor for religious people to participate in charity. Even if there are no obvious persuasive words or recruitment behaviors in religious charity activities, the evocation of the concept of karma, the mention of the holy names of Buddhas and Bodhisattvas, the exhortation of God's teachings, and even of bishops and monks alone are sufficient. The emergence of other religious figures itself has the effect of spreading the religion in a sociological sense. However, the provision of "not spreading religion 
in public welfare and charity activities" is the most sensitive and important component for religious groups to participate in public welfare and charity activities and with the uncertainty in the implementation of the religious charity policy. Therefore, "hiddenreligiousization" has become the best way for organizations to avoid "preaching" in the policy. China's household tracking survey in 2016 showed nearly 11.67 million "hidden Christians" in China. Religious charitable organizations emphasize their non-profit and social services in the secular field, but when applying for cooperation projects with the government, they emphasize the service function in the public sphere, without mentioning the connection with religious groups and their own religious elements, striving to hide their religious overtones. When contacting other religious groups, they emphasize their religious characteristics and beliefs, and maintain relations with these groups and related associations [31].

The development of religious charity organizations is also an important factor affecting policy implementation. A clear legal personality, a scientific and complete operating system, and professional service management can also promote the development of religious charities. According to a survey in Shandong Province, social service organizations, organized by religious groups and people are still in the initial stages of professionalisation: (1) their organizational structure is relatively simple with no specialised division of labour, and the organization's rules and regulations are in a suspended state; (2) some organization leaders have weak awareness of laws and regulations and low levels of education, and they rely mainly on religious beliefs to engage in charitable services. In daily operations, the preferential content of the policy cannot be combined with organizational development, thus the expected effects of the policy cannot be effectively realised. Simultaneously, the focus areas of policy encouragement or restrictions also affect the behavior of target groups. When religious charity organizations believe that policies are strictly regulated in a certain area, they will avoid or withdraw from that area, while the organization's interests are satisfied under the policy. Thus, the target organization will become an important promoter of policy implementation. The stimulus of external factors and the temptation of interests increase the uncertainty of the target group's behavior, thereby affecting the policy's implementation process and results.

\subsection{Environmental Factors Affecting the Implementation of Policies for Religious Charity Activities}

In China, the political environment and leadership (personal) level of understanding and attitude towards religious social services at different periods determine the degree of policy encouragement and support. In addition, different political environments, social environments, and a politically sensitive atmosphere in various regions determine the scale of religious groups' engagement in public welfare and the support and supervision of religious charity activities. The different periods in China can be summed up as follows: (1) In the early days of the founding of the People's Republic of China, the development of religious charity activities was restricted by domestic movements and the intense political environment abroad [32]. (2) In 1982, the Central Committee of the Communist Party of China issued the "The Basic Views and Policies of the Central Committee of the Communist Party of China on Religious Issues in China's Socialist Period" [5]. Thus, based on the working ideas of "religious laws and regulations", religious affairs began the exploratory stage of legal management. (3) In 2012, “Opinions on Encouraging and Regulating Religious Circles' Participation in Public Welfare Charitable Activities" [6] was released, solving the problem of identity recognition that had confounded the development of religious charities, and religious charity activities, thus, gradually developed the "dual track" of relying on policies and regulations. (4) After the Third Plenary Session of the 18th Central Congress of the Communist Party of China, the party, and the government, advanced a strategy to comprehensively promote the rule of law, providing a way to promote the legalization of religious management. (5) In 2017, the newly revised "Regulations on Religious Affairs" [9] marked a new level of legalization of religious work in China [33]. 
However, contemporary Chinese religions present the status quo of "religion outside the religion and faction within the religion", which means that there is no single or dominant religion in China, and there are also different sects within a certain religion, the status quo coupled with the unique nationality and internationality of religion, making the management of religious affairs tense and difficult. In mainland China, there are five major religions with clear organization and strict doctrine, as well as various forms of folk beliefs. There are also many new religious organizations, such as house churches and underground churches that have not been legally registered. Religious denominations are another addition to traditional religious sites. The Internet has become another place for religious charity. In recent years, due to the ineffective supervision of some social organizations, the image and credibility of China's public welfare and philanthropy have received unprecedented doubts [34], especially in terms of donations, services, assistance, and supervision, which was once representative of the public's over-examination. These doubts and challenges also affect religious social service organizations. Even if the government supports charitable activities that have lost the trust of the public, and rely solely on the support of believers, policy implementation will be needed, and it will be difficult to operate for a long period.

\subsection{Tension and Transaction in the Process}

When Smith specifically analyzed the tension factors in the policy implementation process, he used Zollschan's [35] conjecture to construct a tension model at the individual level. This tension can be either malignant or benign. In the policy of religious charity activities, the policy content, the current social environment, religious charity organizations, and government departments (staff) may create tensions and differences in their respective roles, affecting the implementation of current, supporting, and follow-up policies. However, when the various components of the policy implementation process react to tension, pressure, and deadlock, it will lead to the emergence of certain expedient solutions.

The essence of a transaction is to find balance and resolve existing tensions during and after the implementation of policy. Through experimental improvement measures and institutionalization designed and implemented by relevant participants, conflicts or differences in the implementation of public welfare and social service policies for religious groups can be resolved. For example, by setting up "pilots", whether a policy should be continuously promoted, institutionalized or abolished can be determined. Selecting religious charity organizations of different sizes, denominations, and registered identities as "pilots" can provide ways for participating in charitable organizations that adapt to the policy and social environment. For example, the CCC and TSPM in China have gradually added professional committees for social services since 2010, using internal facilities and venues to introduce social services or charitable service projects, and plan to establish religious charity organizations or foundations. These tentative policy practices promote policy improvement.

\section{Sustainable Suggestions}

To effectively implement religious public welfare and charity activity policies, it is necessary to balance the tensions of all parties and create a strong executive force. In view of the current weak locality of religious charity policies, the evasive attitudes and behaviors of religious charity organizations towards policies, and the multiple supervisory layers of government departments, there is an urgent need to establish a policy implementation model led by the government, the main body of the organization, the support of the believers, and the mutual benefit of the community. The legislature attaches great importance to the establishment of a complete system of institutions, the formation of efficient enforcement teams by law enforcement agencies, adherence to legal administration, scientific administration, and innovative management methods and concepts, and creates an environment conducive to the healthy development of a religious charity. Religious charity organizations attach importance to organizational operations and professional services; linking social resources legally and efficiently; strengthening the cooperation and exchange of technology, services, 
and experience in the field of charity; promoting the professional development of religious charities; and changing religious charity organizations or activities from relying solely on religious beliefs and the status quo of providing services with enthusiasm.

\subsection{Making Policies Scientifically and Standardising the Religious Charity Policy System}

The legislature and law enforcement agencies should understand the regularity of religious charity work at this stage, accelerate the pace of legislation, and introduce a series of high-quality and practical policy systems for religious charity activities. First, in the policy agenda and formulation stage, by clarifying the interests of religious charity organizations, religious sites, and individuals, the government can reasonably divide the responsibility boundaries of executive agencies and establish a policy approach that encourages regulations instead of restricting supervision. In the process of formulating and implementing religious and other social welfare policies, religious charitable organizations are included in the target group, and religious charities and charitable activities should be treated equally. Second, the party and government should upgrade effective religious activity policies that have been proven in practice to legal procedures and improve the freedom of religious beliefs, the development of religious charity activities, the registration of religious organizations as legal entities, and the taxation and accounting of religious organizations. Finally, in response to the current serious convergence of local religious policies, the eastern and central regions, where a religious charity has developed rapidly and has strong resources, are encouraged to formulate relevant normative policy documents, highlighting legal registration, legal activities, and tax incentive policies. In western provinces and cities that are strongly influenced by ethnic religions, are weak in philanthropy, and relatively underdeveloped economically, encouragement, support, supervision, and guidance should be provided with the aim of guiding regional policies to adapt to social welfare, charity, and the rule of law in religious affairs.

\subsection{Strict Law Enforcement: Strengthening the Development of Law Enforcement Teams}

Due to the current political and legal environment, law enforcement agencies need to change the originally planned administrative management methods, strengthen the construction of law enforcement subjects [36], and innovate the governance methods for managing religious affairs in accordance with the law. Examples of such changes are as follows. (1) Innovating the governance methods for managing religious charity affairs in accordance with the law. Neither overall management nor management by religious groups should function independently. Instead, an administrative agency should clarify and assign the functions and responsibilities for each system, ensuring a coordinated management of the religious affairs; thus, changing the phenomenon of absence, prevarication, and lack of management in the law enforcement process. (2) Preventing excessive intervention by some departments and the abuse of administrative power. (3) Improving the legal literacy of religious law enforcement teams and adherence to the concept of administration according to law, especially by strengthening the training of grassroots religious staff.

\subsection{Promote the Professionalization of Institutions and Management}

At present, most religious charity organizations in China usually only engage in social charity from the perspective of personal beliefs and lack professionalism. Therefore, professional scholars and policymakers need to jointly discuss and construct service policies that can comply with and promote professional and cultural sensitivity, and strengthen value clarification, respect, client centers, inclusivity, and innovation in professional practice. Religious charity service organizations focus on improving the professionalism of internal staff service theory and practice, and the recruitment of personnel has shifted from focusing on religious background to professional background. They also create conditions for religious social service organizations to communicate with each other and gradually incorporate them into unified industry management. 
On the one hand, open space in terms of policies to encourage the establishment of their own coordination and communication mechanisms within the religious community; on the other hand, religious and quasi-religious social service organizations should join a unified industry association according to their business fields, and conduct professional information exchanges and upgrade training, according to industry rules and standards, achieving industry self-discipline.

\subsection{Referencing Useful Experiences to Build a New Policy Implementation Model}

Hong Kong is a typical representative of developed religious social services and is a model for the coexistence of multiple religions. Religious social organizations respond to and deal with various social problems and needs, at the same time providing experience and reference for the policy development of religious social organizations in mainland China [37]. Hong Kong's policies for religious social organizations have a complete set of systems in terms of identity registration, service provision, tax management, preferential treatment, personnel appointments, and supervision and inspection. "Societies Ordinance" and "Companies Ordinance" and "A Tax Guide for Charitable Institutions and Trusts of a Public Character" issued by the Inland Revenue Department requires the organization to determine its type and structure, without restrictions on religious attributes, which guarantees the freedom of organizations to carry out charitable activities and rights, to encourage religious groups and believers to play a role in the charity activities. Since the entry threshold for charitable organizations is relatively easy, Hong Kong government uses strict taxation and fiscal policies to ensure that religious forces do not deviate from government goals in charitable activities, and to achieve transparency and legitimacy of charitable organizations. In addition, Hong Kong government bids public services in a market-oriented form, stimulating religious charitable organizations to form modern organizations in the process of enhancing the professionalism of their organizations and personnel, and finally forming a relationship in which the government and religious charitable organizations pull each other and work together. By comparing the implementation process of policies in Hong Kong, it can be concluded that there are insufficient designs in the pertinence, clarity, operability, and effectiveness of policy rules for religious charity activities in mainland China. The separation of religion and service, the integration of religious resources and government resources, and internal review unification with external supervision are important issues faced by religious charity groups during the process of social transformation. By learning from mature policy implementation experiences and models, at home and abroad, the current conflicts between religion and charity, religious social organizations, and government management and supervision departments, policy content, and the development of religious social organizations can be resolved, thus, guiding religious charities on the road of sound development.

Author Contributions: Conceptualization, X.S.; writing-original draft X.S.; writing-review and editing, J.G. and Z.F.; project administration, J.G. All authors have read and agreed to the published version of the manuscript.

Funding: This research was funded by the Major Project of Humanities and Social Sciences Research Base of the Ministry of Education, grant number 12JJD730002.

Institutional Review Board Statement: Not applicable.

Informed Consent Statement: Not applicable.

Data Availability Statement: The data presented in this study are available on request from the authors.

Conflicts of Interest: The authors declare no conflict of interest. 


\section{References}

1. The White Paper. China's Policies and Aractices on Protecting Freedom of Religious Belief; The State Council Information Office of the People's Republic of China: Beijing, China, 3 April 2018. Available online: http:/ /www.china.org.cn/government/whitepaper/ node_8004087.htm (accessed on 23 November 2021).

2. Lu, Y.F.; Wu, Y.; Zhang, C.N. How many Protestants are there in China: An estimate based on China family panel studies. Open Times 2019, 1, 165-178.

3. Cheng, M.M.C. House Church Movements and Religious Freedom in China. China An International Journal 2003, 1, 16-45. [CrossRef]

4. MCA (Ministry of Civil Affairs of the People's Republic of China). 2017 Statistical Bulletin of Social Service Development in 2017. 2018. Available online: http:/ / www.mca.gov.cn/article/sj/tjgb/2017/201708021607.pdf (accessed on 3 November 2021).

5. CPC (The Communist Party of China). The Basic Views and Policies of the Central Committee of the Communist Party of China on Religious Issues in China's Socialist Period. 1982. Available online: https://www.chinabuddhism.com.cn/fg/fg/2012-03-16 /545.html (accessed on 23 November 2021).

6. NRAA (National Religious Affairs Administration). Opinions on Encouraging and Regulating Religious Circles' Participation in Public Welfare Charitable Activities. The United Front Work Department of CPC Central Committee and National Development and Reform Commission, Ministry of Civil Affairs of the People's Republic of China, Ministry of Finance of the People's Republic of China, State Taxation Administration; National Religious Affairs Administration: Beijing, China, 2012. Available online: http: //www.sara.gov.cn/gfxwj/316207.jhtml (accessed on 3 November 2021).

7. State Council of the People's Republic of China, Guiding Opinions on Promoting the Healthy Development of Charity. 2014. Available online: http:/ / www.gov.cn/gongbao/content/2015/content_2799012.htm (accessed on 3 November 2021).

8. State Council of the People's Republic of China. General Provisions of the Civil Law. 2017. Available online: http://m.law-lib. com/law/law_view.asp?id=557671 (accessed on 3 November 2021).

9. State Council of the People's Republic of China. Regulations on Religious Affairs, Decree No. 686 of the State Council of the People's Republic of China. 2017. Available online: http:/ / www.sara.gov.cn/flfg/330350.jhtml (accessed on 3 November 2021).

10. Wang, Z. An Outline of Chinese Christian History; Shanghai Classics Publishing House: Shanghai, China, 2004.

11. Yanjing Theological Seminary. College Introduction. 2021. Available online: http://www.yjts2013.cn/about.aspx (accessed on 28 November 2021).

12. Smith, T.B. The Policy Implementation Process. Policy Sci. 1973, 4, 197-209. [CrossRef]

13. McCulloch, G. Documentary Research in Education, History and The Social Sciences; Routledge Falmer: London, UK, 2004.

14. ERAC (Ethnic and Religious Affairs Commission) of Shandong Province. Plan on Organising the Province's Religious Circles to carry out Public Welfare Activities. 2015. Available online: http:/ / mzw.shandong.gov.cn/articles/ch01986/201505/3D21CA074F61-499C-95DC-C1C72B077082.shtml (accessed on 27 November 2021).

15. ERAC (Ethnic and Religious Affairs Commission) of Jinan, Shandong Province. Implementation Opinions on Encouraging and Regulating Religious Circles to Engage in Public Welfare and Charity Activities. 2015. Available online: http://mzw.shandong. gov.cn/articles/ch01986/201510/E040CB60-8C8F-4B76-928A-3A2E4CC9ABA6.shtml (accessed on 27 November 2021).

16. CCC (China Christian Council); TSPM (The National Committee of the Three-Self Patriotic Movement of the Protestant Church in China). Annual Report on Social Service Ministry 2018. The Protestant Churches in China. 2019. Available online: http: //www.ccctspm.org/proworker (accessed on 1 December 2021).

17. CCC (China Christian Council); TSPM (The National Committee of the Three-Self Patriotic Movement of the Protestant Church in China). Outline of the Five Years Plan for Promoting the Indigenization and Contextualization of Christianity in China (2018-2022). The Protestant Churches in China. 2018. Available online: http://www.ccctspm.org/cppccinfo/10283 (accessed on 1 December 2021).

18. Ding, H. An Institutional Analysis of My Country's Current Policy Implementation Obstacles and Countermeasures. Political Sci. Res. 2002, 1, 28-35.

19. NRAA (National Religious Affairs Administration). Circular of the State Administration for Religious Affairs on Launch "Religious Charity Week" in 2015. 2015. Available online: http:/ / www.pkulaw.cn:83 / fulltext_form.aspx?Gid=249209\&Db=chl (accessed on 3 November 2021).

20. NRAA (National Religious Affairs Administration). Measures for the Implementation of Administrative Licensing Projects for Religious Affairs. 2018. Available online: http://www.gov.cn/gongbao/content/2018/content_5301878 (accessed on 3 November 2021).

21. NRAA (National Religious Affairs Administration). Administrative Measures of Religious Bodies. 2019. Available online: http:/ / www.sara.gov.cn/bmgz/322211.jhtml (accessed on 3 November 2021).

22. NRAA (National Religious Affairs Administration). Administrative Measures of Religious Personnel. 2021. Available online: http:/ / www.sara.gov.cn/bmgz/351322.jhtml (accessed on 3 November 2021).

23. Weller, R.P.; Huang, C.J.; Wu, K.; Fan, L. Religion and Charity: The Social Life of Goodness in Chinese Societies; Cambridge University Press: Cambridge, UK, 2017.

24. Wang, X. Yunnan Baoshan Evangelical Voluntary Detoxification Center: New Life in the Garden. Christ Times. 5 April 2016. Available online: https://www.christiantimes.cn/news/20683/ (accessed on 1 December 2021).

25. Yang, T. A New Model of the Trusteeship of the Public Service Equipment in Community. Sociol. Study 2001, 3, 77-86. 
26. Nu, Z. The Review and Prospect of Religious Groups' Involvement in Public Services and Charitable Works in China. China Religion 2011, 4, 11-17.

27. Wu, Y. Religious Circles Hope to Have More Space to Participate in Elderly Care Service. China Ethnic News, 14 March 2017.

28. Yang, T. Non-Organization Evaluation: A Case Study of the Luoshan Civil Center; Huaxia Publishing House: Beijing, China, 2001.

29. Zhao, L.; Hui, Z. Research on the Foundation and Advantage of Religion Participating in Endowment in Transition Society. Popul. J. 2012, 5, 64-71.

30. Fuqiang, Y. Taking Multiple Measures Simultaneously to Strengthen Guidance-Shandong Province Encourages and Regulates Religious Circles to Carry Out Charitable Activities. China Religion 2017, 7, 64-66.

31. Bo, L. Research on Several Legal Issues of Religious Charity. China Religion 2013, 3, 72-73.

32. Wang, Z. Maoism and Grass-Roots Religion: The Communist Revolution and the Reinvention of Religious Life in China. J. Contemp. Asia 2021, 4, 693-695. [CrossRef]

33. Peng, L. The Legalization Process of Chinese Religion: In Annual Report on Religions in China; Jin, Z., Qiu, Y., Eds.; Social Sciences Academic Press: Beijing, China, 2008; pp. 261-278.

34. Cui, Y.; Sun, Y. The Dilemma and Path Selection of the Development of Religious Charity in the Transition Period. Ideol Front. 2014, 6, 72-77.

35. Zollschan, G.K. Working Papers on the Theory of Institutionalization. In Explorations in Social Change; Zollschan, G.K., Hirsch, W., Eds.; Houghton Mifflin: Boston, MA, USA, 1967.

36. Feng, Y.; Xue, M. Research on the Construction of Chinese Religious Charity Legal System. J. Wuhan Univ. Philos. Soc. Sci. Ed. 2014, 6, 87-95.

37. Tao, F.; Ling, C. Cooperative Charity: The Relationship between Hong Kong Regional Government and Religious Charity Organizations and Its Enlightenment. Dongyue Trib. 2012, 1, 106-114. 